\title{
TORCH Syndrome
}

National Cancer Institute

\section{Source}

National Cancer Institute. TORCH Syndrome. NCI Thesaurus. Code C98609.

A syndrome that results from a group of infections that affect the fetus or the newborn.

The group of infections includes Toxoplasma gondii, rubella, cytomegalovirus, herpes

simplex virus, and other infections. The other infections include varicella-zoster virus,

hepatitis B virus, human immunodeficiency virus, parvovirus B19, and syphilis. Signs and

symptoms include fever, feeding difficulties, petechial rash, jaundice,

hepatosplenomegaly, chorioretinitis, and microcephaly. 